\title{
Motivação e Música no Trabalho: Relato de Experiência.
}

\author{
Pascoal, Melissa \\ Hospital Estadual Vila Alpina — melissa.pascoal@gmail.com
}

Introdução o trabalhador da área da saúde enfrenta diversas situações e fatores em seu ambiente de trabalho que podem afetar a sua integridade, física, emocional, psíquica e sua motivação. a motivação no trabalho é vista como "aquilo que provoca o movimento", ou seja, os aspectos que fazem com que os colaboradores se sintam bem e dispostos no trabalho para realizar suas tarefas. Muitos autores têm realizado estudos e apontado a necessidade das instituições de saúde proporcionarem ambientes e momentos de cuidado para os cuidadores, realizando ações que favoreçam o cuidado de si, promovendo o bem estar e a motivação. 1 a música se constitui como expressão artística e cultural importante e universal e embala o cotidiano da vida social, afetiva e profissional das pessoas, e sua utilização para melhorar o bem estar físico, emocional e mental é praticada desde tempos antigos. Visando trazer descontração, relaxamento, diversão, oportunidade de reconhecimento no ambiente de trabalho, o hospital realizou um evento In Concert para que os colaboradores demonstrassem seus talentos musicais, cantando, dançando e tocando instrumentos. o objetivo é utilizar a musica como mecanismo de expressão e desta forma trazer mudanças ao ambiente de trabalho, impactando na motivação do colaborador. Métodos Trata-se de um relato de experiência de um evento realizado em 11 de dezembro de 2013, para a apresentação dos colaboradores do hospital, demonstrando seus talentos musicais. Resultados Através desta apresentação pode se observar o impacto que a musica provoca no ambiente e nos colaboradores. a apresentação foi composta por apresentações de cantores solo, em duetos e trios, além do Coral. Alguns colaboradores se apresentaram em audições instrumentais com piano, violão, guitarra e sanfona. para complementar a apresentação, que foi com o tema de Amizade, ouve a leitura de um poema feito por uma colaboradora especialmente para o evento. Diversos colaboradores assistiram as apresentações que foram emocionantes, houve participação da platéia, o que evidencia o fortalecimento dos vínculos. Foi um momento dedicado ao cuidado com os colaboradores, para realizarem algo que gostam e se sentem bem, impactando diretamente em seu bem estar e motivação. Conclusões: a música é um instrumento facilitador de grande riqueza, que pode ser utilizado como veículo para a motivação no ambiente de trabalho, trazendo bem estar, relaxamento e descontração. Bibliografia Oliniski SR, Lacerda MR. Cuidando do cuidador no ambiente de trabalho: uma proposta de ação. Ver Bras Enferm 2006; jan-fev; 59(1): 100-4.

Pascoal, Melissa. Motivação e Música no Trabalho: Relato de Experiência.. In: Anais do Congresso

Internacional de Humanidades \& Humanização em Saúde [= Blucher Medical Proceedings, num.2, vol.1]. São Paulo: Editora Blucher, 2014. ISSN 2357-7282

DOI 10.5151/medpro-cihhs-10205 